\title{
What Drives Efficiency on the Portuguese Gas Distribution?
}

\author{
V. Marques, P. Almeida, M. Cunha, M. Paço, M. Rocha, A. Trindade
}

\begin{abstract}
The Portuguese natural gas sector is still growing, with a history of less than two decades. Consequently, the impact of regulatory reform is evidently recent. The aim of this paper is to assess the performance of the Portuguese gas distributors in order to define the efficiency targets for the regulatory period, 2010-2013. It also conducted further analysis in order to determine the best level of attainable operating costs by deriving the major costs driver of the Portuguese gas distributors. Therefore, the focus was on the deterministic frontier method, Data Envelopment Analysis (DEA) accounting for variable returns to scale (VRS). This technique allowed the computation of $X$-factors for each firm. The study suffered from data problems since the sector is very recent and the set of comparable companies is small. In order to avoid misspecifications or misinterpretations, firms were divided into three main groups with different scale factors and exogenous factors were also considered. The cross-section analysis was crossed with a dynamic one using panel data methodology.
\end{abstract}

Keywords: Regulation, Data Envelopment Analysis, Portuguese natural gas distribution.

JEL Classification: L15, L51, L94. 


\section{Introduction}

An efficient allocation of resources is associated with the theoretical concept of perfect competition. However, resources are often allocated in combinations that are socially suboptimal, that coupled with highly concentrated markets highlight considerable inefficiencies in production and resources allocation. The measurement of efficiency is not only important to the economic theorist but also for the economic policy maker (Farrell, 1957). Consequently, efficiency analysis has played a relevant role in regulating network industries, particularly electricity and natural gas (von Hirschhausen et al., 2006).

Natural gas sector is a network where particular segments, such as distribution and transport, are considered as natural monopolies, meaning that the cost function of the firm is subadditive over the relevant output range (Tirole, 1988). The presence of asymmetric information boosts further potential inefficiencies. The answer of this problem has been regulation through prices, network access, service quality and/or entry (Joskow, 2005).

As liberalisation and competition are introduced in the gas market, specifically in the segments of generation and supply, incentive based schemes have been increasing in the number of countries for regulation of the subadditive segments. The incentive regulation proposed by Littlechild (1983) has been giving higher evidences of efficiency than the traditional rate-of-return regulation (Crew and Kleindorfer, 1996). The incentive regulation attempts to provide enough incentives to firms in minimizing costs and improving efficiency. There are several categories of incentive based schemes which are generally based on benchmarking. This technique compares a certain measure of actual company's efficiency against a reference performance in order to identify the most efficient production frontier (Jamasb and Pollitt, 2001). From a regulatory point of view, "benchmarking is used to infer the level of attainable costs and in setting the $X$-factors for periodic price reviews" (Giannakis et al., 2005, p. 2257). However, the youth and peculiarities of the Portuguese gas sector make difficult the application of any benchmark.

The Portuguese natural gas sector is growing, with a history of less than two decades. Consequently, the impact of regulatory reform is evidently recent in the Portuguese gas sector. Only by the end of the first regulatory period, in 2009, it was possible to analyse the sector by distinguishing the potential efficiency gains of the gas distributors and ultimately implement an incentive based regulation.

The aim of this paper is to assess the performance of the Portuguese gas distributors in order to define the efficiency targets for the regulatory period, 2010-2012. We focus on the deterministic frontier method, Data Envelopment Analysis (DEA). This is mainly due to Portuguese particularities: namely the low number of observations and the 
existence of highly differences among companies. Indeed, the data available refers to a very short period, 2008 and 2009, because distribution and supply were still bundled in 2007. Also, there is a high difficult to compare Portuguese gas distributors for several reasons being one the different maturities of each firm. Some companies began their activity before 1997 whereas others began only in 2007. This paper also addresses an analysis of the main inputs, outputs, cost drivers of the gas distributors and exogenous factors. Notice that the present study is the first efficiency analysis of the Portuguese gas distributors to date. The computation of a benchmarking analysis has been undertaken to set the $X$-factors needed in price-cap regulation as an incentive mechanism that rewards or punishes companies (Farsi and Filippini, 2004). Such an analysis when implemented to the companies has major consequences to the various economic agents. Therefore, the results should not be carried out in a mechanical way but rather as a fundamental instrument of the sector knowledge and the regulator decision-making (Carrington et al., 2002). In the present case, this recommendation has special relevance since the sector is recent and the set of comparable companies is small, resulting in a small sample. Additionally, the sector is so recent that hardly is comparable with other countries and foreign companies. These aspects lead to data problems and so a direct application of the DEA results could lead to misspecifications and misinterpretations. Therefore, the $X$ factors given by DEA have not been applied directly to firms but rather by groups of firms. Dimension, population density of the area and maturity of each firm have also been considered. Since firms are different with each other especially in terms of fixed and variable costs, it has been undertaken a dynamic analysis in order to inference the percentage of fixed and variable costs of each firm.

The rest of the paper proceeds as follows: Section 2 provides information on the regulatory regime for Portuguese gas distributors and the main characteristics of the various companies in the distribution of gas. Section 3 presents a brief literature review. Section 4 describes the main frontier method applied in order to measure the performance of the gas distributors. Section 5 presents the data used and the estimation results. Section 6 provides some regulatory implications. The main conclusions are summarized on Section 7.

\section{Regulation of gas distribution}

Over the last years, incentive regulation and benchmarking analysis have become widely used in regulation of public utilities. Since the discovery of the Averch-Johnson effect 
(Averch and Johnson, 1962), rate-of-return regulation has been commonly criticized hence the increased use of incentive based regulation.

The major types of incentive regulation have been price caps (or revenues caps), profit sharing, yardstick regulation, banded rate-of-return regulation and menus. However, price caps have become the incentive regulation mechanism mostly adopted by regulators. The price cap mechanism operates for a pre-established time period Joskow, 2005). This period corresponds to three years in Portugal electricity and natural gas regulation. At the end of this date, a new starting price and a new $X$-factor are defined after another cost analysis and firms' performance review. This mechanism allows the combination of two characteristics: incentives for cost reductions as well freedom and incentives for price rebalancing (Vogelsang, 2002).

Natural gas reforms focus on the introduction of competition in generation and supply whereas distribution and transport have been less affected due to their natural monopoly nature. Several regimes have been applied to gas distribution but the main one due to its potential benefits has been incentive regulation.

Portuguese natural gas distribution was initiated on 1997 with 5 companies mainly on coastline. Until 2006, the gas sector was organized as a vertical integrated monopoly, without switching possibilities. The Decree Law no $140 / 2006$, on July, $26^{\text {th }}$, modified the industry structure by establishing unbundling on the gas market. By the end of 2006, the ownership unbundling occurred with the separation of the transport segment from the vertically integrated firm. The same Decree Law established a few points related to the market opening, such as the switching opportunity to the electricity generators, since 2007. On January 2008, the switching was extended to clients with an annual consumption higher or equal than 1 million $\mathrm{m}^{3}$. From January 2009, it covered the clients with an annual consumption higher or equal than $10000 \mathrm{~m}^{3}$. Lastly, on January 2010, the Decree Law embraced all clients.

The unbundling between the distribution and supply activities occurred on the beginning of 2008. Furthermore, in 2008, few distributors were still on their introduction life cycle phase or in their growth phase while others firms were already expanding maturity. This reality led to several problems related to data: the sample is relatively small and firms are not readily comparable with each other. These facts allied with the liberalisation process, had conditioned the $X$-factors setting.

\subsection{Main features of the Portuguese gas distribution}

In 2008, the Portuguese gas distribution was provided by 6 concession companies (Beiragás, Lisboagás, Lusitaniagás, Portgás, Setgás and Tagusgás) and 5 licensed 
companies (Dianagás, Duriensegás, Medigás, Paxgás and Sonorgás). The concession ones generally have a higher maturity than the licensed ones. The four biggest distributors (Lisboagás, Lusitaniagás, Portgás and Setgás) held, in 2008, a market share of 90.8\% regarding the number of customers ${ }^{1}$ and $92.8 \%$ related to delivered gas. From the 11 distributors, 8 of them belong to the GALP Group (Beiragás, Setgás, Dianagás, Lusitaniagás, Medigás, Duriensegás and Paxgás); 1 belongs to the EDP Group (Portgás); 1 to the Lena Group (Tagusgás) and 1 to the Dourogás Group (Sonorgás).

As Portuguese gas distribution is especially recent, even the companies with a higher maturity in the market are still on an investment phase. However, it was on the first six years (1997-2002) that the main investments were made. From this date on, the investments are essentially directed to the secondary network. The gas distribution network in Portugal increased from 2759 km in 1997 to 15597 km in 2007.

Figure 1- Area covered by natural gas and market share by each firm, 2008

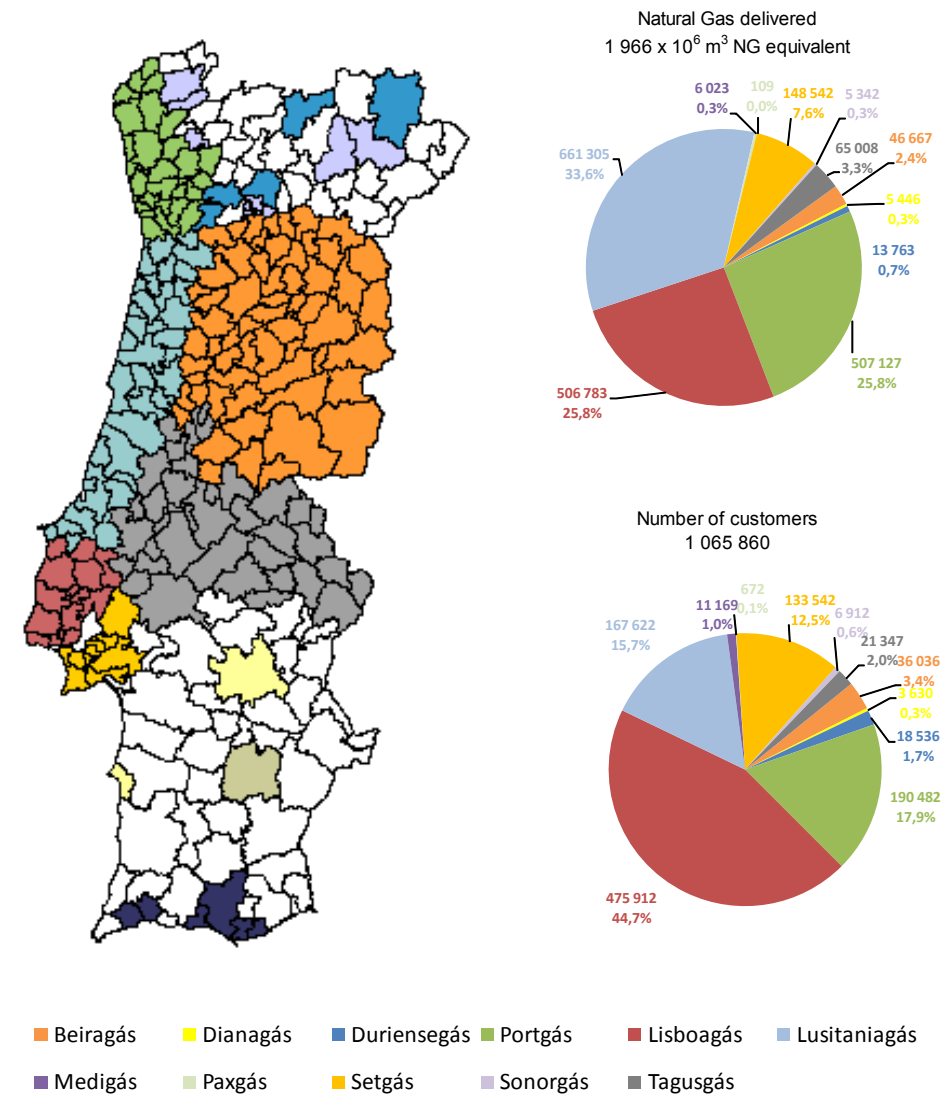

Source: Natural gas distributors

${ }^{1}$ Notice that until 2007 this number regards to the customers, after this date it regards to supply points. 
Figure 1 identifies the area covered by each firm and also its market share in terms of gas delivered and in terms of number of customers. Distribution of natural gas is already present in $93 \%$ of the continental Portuguese population and $65 \%$ of national territory. Nevertheless, there is only 1 million (roundly) gas consumers in Portugal where almost half has its gas distributed by Lisboagás.

Figure 2 - Sales of natural gas and propane², 1997-2007

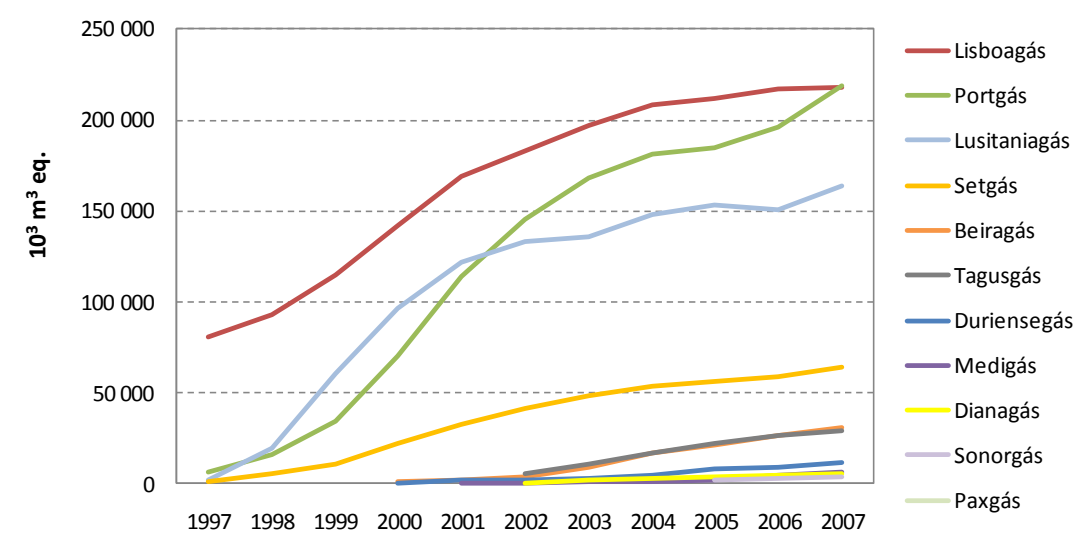

Source: Natural gas distributors

Between 1997 and 2007, the average annual growth rate of the volume of gas sales was around $24 \%$. In 2007, the total gas sales by the licensed distributors represented less than 5\%. When considering Portgás, Lisboagás and Lusitaniagás, these three companies represented $80 \%$ of the total sales in 2007 . Regarding the number of clients, the number exceeded 1 million in 2007. Between 1997 and 2007, the average annual growth rate was roundly $15 \%$. Though, this tendency has been suffering a reversal in the last few years.

Since 2001, the number of employees in Portuguese gas distributors is quite stable, approximately 600 employees. Most companies, instead of recruiting have been responding to their needs through outsourcing. This management option set problems when choosing the variables in a benchmarking analysis. When firms outsourced, they do not have to use their physical resources, being the costs registered on the External Supplies and Services accounting line. Thus in the present case, physical measures should not be used when evaluating potential efficiency gains.

\footnotetext{
2 The information available did not allow a separation between data referred to natural gas and to propane. It was decided to not separate the data by gas type in order to avoid potential errors. Furthermore, there has been a common practice by firms starting their activity with propane and after convert propane customers into natural gas customers.
} 
Figure 3 shows the relation between the length of the network built versus the number of customers, i.e., the network saturation. We may conclude that the network has been built accordingly to supply foreseen new customers.

Figure 3 - Network Saturation, 1997-2007

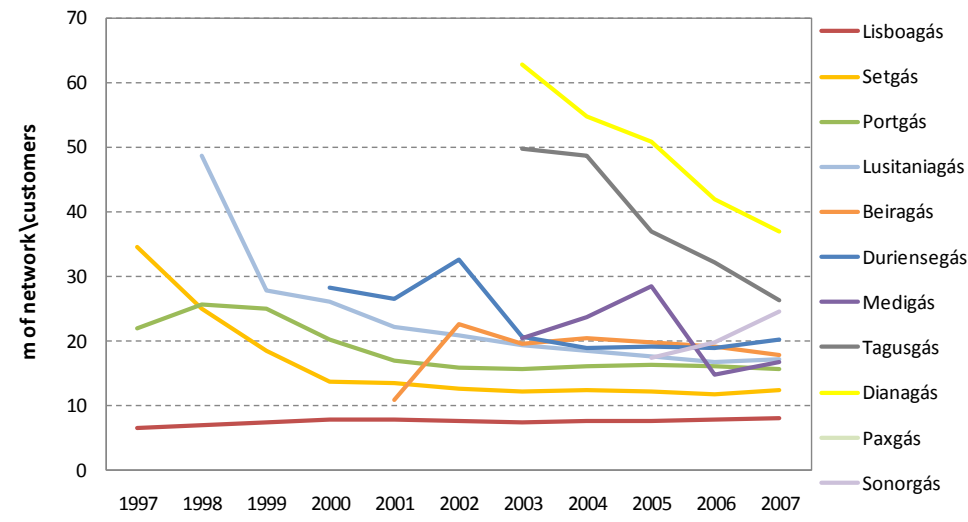

Source: Natural gas distributors

The next figure shows the net operating expenses evolution (excluding amortizations). These are computed as follows:

- (+) Operating expenses: External supplies and services, Employee costs, Interest, Provisions, Adjustments and Other operating expenses.

- (-) Operating income: Sales, services rendered and other operating income. As referred above, distribution and supply were bundled until 2007. Therefore, the data related to OPEX costs over the period 1999-2007 concerns both activities.

Figure 4 - Net operating expenses, 1999-2007

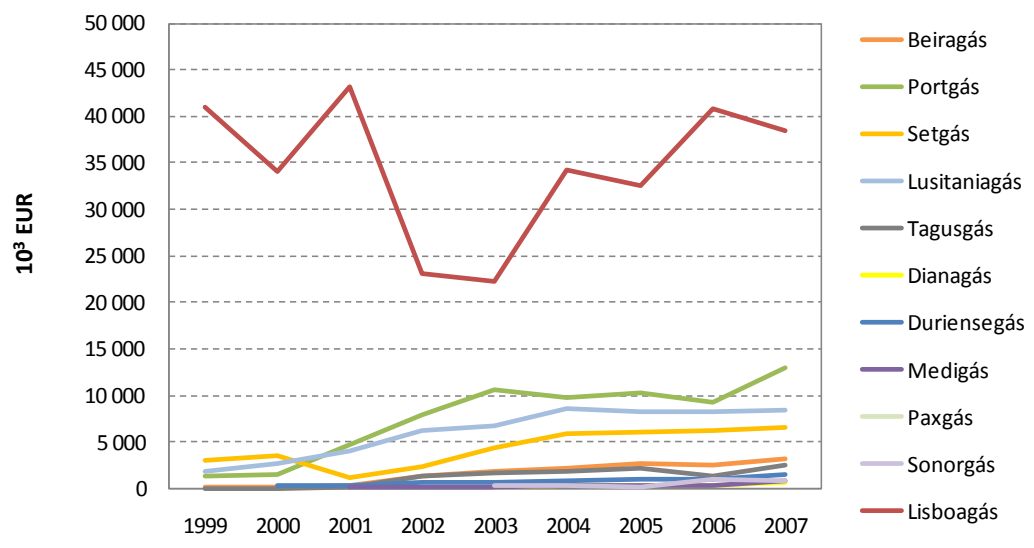

Source: Natural gas distributors 


\subsection{Measuring Efficiency}

Farrell (1957) demonstrated empirically that economic efficiency can be decomposed into allocative efficiency and technical efficiency. The former refers to the ability of combining inputs and outputs in optimal proportions given its prices. While technical efficiency refers to the ability of producing a given output with the least amount of inputs (Lovell, 1992). Economic efficiency occurs when both allocative and technical efficiency are achieved. According to Farrell (1957, p. 253), it is crucial to "know how far a given industry can be expected to increase its output by simple increasing its efficiency, without absorbing further resources".

There are several benchmarking methods that provide an efficiency analysis. The most accessible and easy application is the partial productivity measure. However, this method involves some drawbacks and limitations. Unlike partial ratios methodology, most of the remaining methodologies seek to measure the distance, in terms of efficiency, between the analyzed companies performances and the efficient production (or cost) functions. Therefore, the choice for empirical techniques that measure the efficient frontier, such as DEA, Stochastic Frontier Analysis (SFA), OLS, Corrected OLS (COLS) or Modified OLS (MOLS), is more appealing. According to Carrington et al. (2002), the employment of several measures of efficiency reduces the risk of misinterpretations due to omitted variables or/and other potential issues. Consequently, in this section, partial ratios and a correlation analysis will be undertaken, whereas the empirical techniques will be left for the following sections.

Partial productivity measures correlate outputs and inputs. This method allows measuring efficiency in a broader way since it does not require any cost function determination or any specific relationship between inputs and outputs. The next table shows an application of these measures to the Portuguese gas distributors regarding the performance of each distributor. The performance indicators relate the operating costs (OPEX) with several outputs present in the distribution activity, as network length, volume of gas delivered and number of customers. The partial ratios reported in table 1 provide some insights on the relative performance. Lusitaniagás, Portgás and Setgás present the most efficient results when compared to the rest of the distributors. However, for the others distributors, conclusions are harder to make. Therefore, partial ratios can be highly informative on the extremes but less accurate on the average.

Notice that there is a significant distinction between the licensed and the concession companies on the operating costs. This potential difference might be explained by relative economies of scale. 
Table 1 - Performance Indicators, 2008

\begin{tabular}{lr|r|r|r|} 
& $\begin{array}{c}\text { Net operating } \\
\text { Costs } \\
\text { EUR }\end{array}$ & $\begin{array}{c}\text { Operating Costs } \\
\text { per unit delivered } \\
\ell / 1000 \mathrm{~m}^{3}\end{array}$ & $\begin{array}{c}\text { Operating Costs } \\
\text { per km of network } \\
\ell / \mathrm{km}\end{array}$ & $\begin{array}{c}\text { Operating Costs } \\
\text { per customer } \\
€ / \text { no. }\end{array}$ \\
\hline Beiragás & 2865957 & 61 & 4477 & 80 \\
Dianagás & 584557 & 107 & 4912 & 161 \\
Duriensegás & 2075970 & 151 & 4978 & 112 \\
Portgás & 8999511 & 18 & 2975 & 47 \\
Lisboagás & 27544808 & 54 & 6912 & 58 \\
Lusitaniagás & 8095169 & 12 & 2842 & 48 \\
Medigás & 512420 & 85 & 2847 & 46 \\
Paxgás & 273893 & 2513 & 10956 & 408 \\
Setgás & 5641447 & 38 & 3414 & 42 \\
Sonorgás & 1777272 & 333 & 8886 & 257 \\
Tagusgás & 3385245 & 52 & 4942 & 159 \\
\hline Total & 61756249 & & & \\
\end{tabular}

Source: Natural gas distributors

Exogenous factors such as population density, maturity and industry gross added value (GVA) per capita highly influences the performance of each gas distributor. When implementing an incentive regulation is essential consider such factors in order to evaluate possible deviations from the efficiency frontier of a given firm.

The information in table 2 regards certain factors that might influence the performance of the local distributors. Some of these factors respect to social-economic areas of concession (estimated gross value added per capita, estimated industry GVA per capita) or geographic (population density, average temperature, and others). In demographic terms, there are clearly three main groups: a first one that contains Portgás, Lisboagás and Setgás; the second group includes Lusitaniagás, Medigás and Duriensegás and the third regards the lowest population density areas supplied by Beiragás, Dianagás, Paxgás, Sonorgás and Tagusgás.

Table 2 - Operating Indicators and Characteristics of Portuguese Gas Distributors, 2008

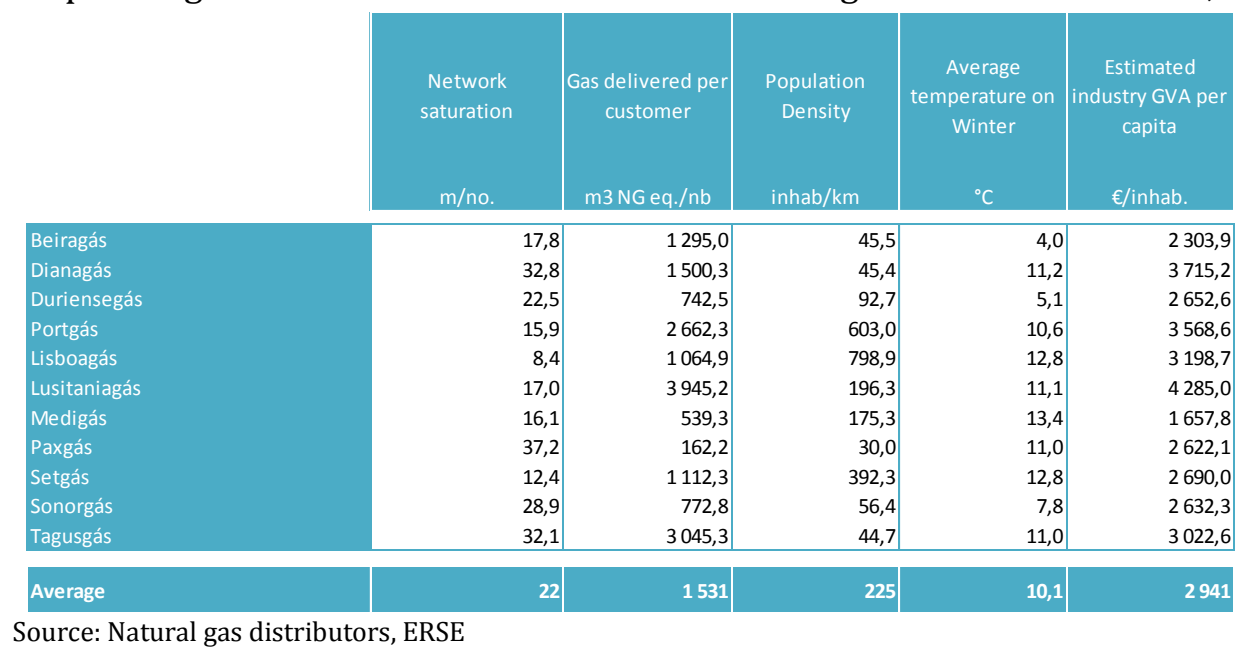


Besides partial ratios, correlation analysis might enlarge the knowledge of the main variables that influence the gas distribution as well as the identification of possible relationships or trade-offs. As it may be observed on the graphs below, there is a highly negative correlation between density population and network saturation. Maturity is negatively correlated with company's performance ${ }^{3}$ whereas network saturation is a positively correlated with operating costs.

Figure 5 - Correlation analysis, 2008
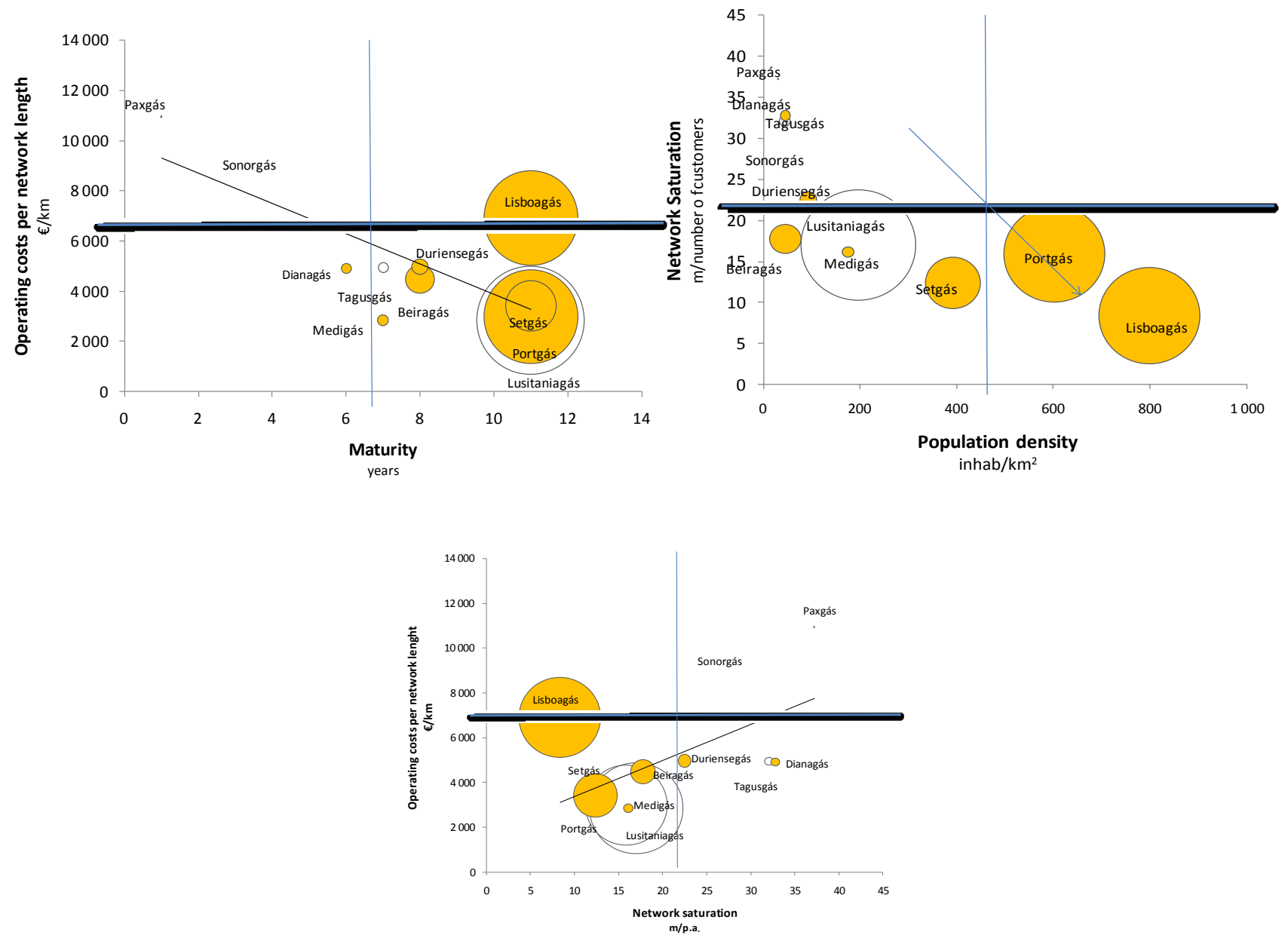

Note: The circle size is related to size of the company's turnover.

The present analysis is fundamental since it shows the impacts that exogenous factors such as maturity and population density may have on the performance of each gas distributor. Thus, company's performance reflects, to some extent, the conditions under which these firms perform their activities.

\footnotetext{
3 Company's performance relates to operating costs per gas delivered, operating costs per number of customers and operating costs per network length.
} 


\section{Empirical Literature Review}

Regarding empirical literature, technical approaches like COLS, DEA and reference methods are frequently used in the natural gas sector whereas SFA is less applied.

Carrignton et al. (2002) applied SFA, COLS and DEA methodologies in order to derive measures of efficiency for Australian gas distributors relative to U.S. counterparts. However, the results present in the study are only concerning DEA methodology. The authors presented as results, an average technical efficiency between 73\% (considering constant returns to scale) and $82 \%$ (considering variable returns to scale) and a scale efficiency of 89.9\%. Zorić et al. (2009) justified the non-application of the SFA method due to the limited sample size. Hawdon (2003) also applied a DEA approach to the natural gas industry with the support of bootstraping technique. A major difficulty in these studies has been associated with the sample size. Therefore, several authors had proceeded to a mixture of countries and companies in order to surpass this issue. If this approach might well surpassed this issue it might create others since observations must be comparable with each other. The choice of countries with different realities might well lead to a skewness problem.

Erbetta and Rappouli (2008) analysed 46 gas distributors. The results indicate a medium level of technical efficiency between 63 and 66\% whereas the scale efficiency is higher and appears between 80 and 83\%. The authors also stated that the inclusion of firms with a higher consumer's density underestimates the technical efficiency and overestimates the scale efficiency. The study concluded that the optimum scale is hit with 65000 clients and 150 million $\mathrm{m}^{3}$ of gas sold. The study by Zorić et al. (2009) concluded that the average efficiency of Slovenian companies is between $52 \%$ (considering variable returns to scale) and $67.4 \%$ (constant returns to scale).

Haney and Pollitt (2009) provide an international survey about the benchmarking techniques used by several energy regulators from 40 different countries. From the total survey respondents', eight used benchmarking techniques in the natural gas sector while twenty used on the electrical sector. This large difference between both sectors might be explained by the distinction on the growth phase since the gas sector is less developed than the electrical one. Furthermore, electricity is usually seen as an essential good which increases its relative importance. In terms of methodologies, methods such as COLS, DEA and reference methods are the most used whereas SFA is less applied in the gas sector.

\section{Methodology}


As was already been noted, Portuguese gas distribution is very recent with a small set of comparable firms. Unbundling of distribution and supply gas activities has been a reality only since 2008. Therefore, the frontier method applied is the Data Envelopment Analysis (DEA). This methodology was developed in 1978 by Charnes, Cooper and Rhodes considering constant returns to scale, being extended for variable returns to scale in 1984 by Banker, Charnes and Cooper.

DEA is a non-parametric method based on linear programming to construct a linear efficiency frontier. This methodology can be input or output oriented. The latter models seek to maximize the output vector for a set of inputs quantities; whereas the former minimize the inputs over a given quantity of outputs.

The aim of such approach is to define a frontier envelopment surface for all observations. The surface is determined by the units that lie on it, the efficient decision making units (DMU). The ones that do not lie on the surface are inefficient (MurilloZamorano, 2004). Therefore, we begin by assuming that there exists a production frontier and an ideal production point that companies attempt to achieve. Different distances from the surface will be observed since there is heterogeneity across companies.

In non-parametric methods, such as DEA, there is no need to specify a function for the cost frontier contrary to the parametric approaches. It also requires less stringent knowledge and less number of observations. Parametric approaches like SFA, allow separating the inefficiency effect from the statistical noise however it demands high datasets. SFA approaches incorporate the idea that certain deviations from the frontier might be explained by exogenous factors that the given firm might not control. Any misspecification of the model would be translated as an increased inefficiency which is clearly a disadvantage (Greene, 2008).

The DEA model developed in 1978 imposed three restrictions: constant returns to scale (CRS), convexity of a set of feasible input-output combinations and strong disposability of inputs and outputs. This model is next formalized.

Given a set of $N$ firms (or DMUs) characterized by an input-output vector with $M$ outputs and $K$ inputs, a matrix $K \times N$ inputs and a matrix $M \times N$ outputs are built. For each firm $i$ (or unit), outputs and inputs are respectively $y_{i}$ and $x_{i}$. The efficiency scores of the $i$ th firm can be determined by the following mathematical programming formulation,

$$
\begin{aligned}
& \min _{\theta, \lambda} \theta \\
& \text { s.t. }\left\{\begin{array}{c}
-y_{i}+Y \lambda \geq 0 \\
\theta x_{i}-X \lambda \geq 0 \\
\lambda \geq 0
\end{array}\right.
\end{aligned}
$$


where $\theta$ is the efficiency score $(\theta \leq 1)$ with a value of 1 indicating a point on the surface or frontier; $\lambda$ is a $N \times 1$ vector of constants that represents the weight of each firm within the sample. The aim is to compute the linear combination of referents that for each firm minimizes the value of $\theta$. The constant returns to scale restriction assumes that all firms are producing at an optimal scale which in the real world might not be true. The DEA extension of 1984 allowed a further assumption of variable returns to scale (VRS) by adding the convexity constraint $\sum_{i}^{n} \lambda_{i}=1$ to the model formulated above. This constraint guarantees that each firm is only benchmarked against firms with similar size.

The next table compares the different methodologies in terms of advantages and drawbacks.

Table 3 - Parametric and no-parametric advantages and drawbacks

\begin{tabular}{|l|l|l|}
\cline { 2 - 3 } \multicolumn{1}{l|}{} & Non parametrical methods (DEA) & Parametrical methods (SFA, COLS) \\
\hline Advantages & $\begin{array}{l}\text { Do not require to know the cost or production } \\
\text { functional forms. } \\
\text { Do not need a large number of observations. } \\
\text { Allow to identify which companies are on the } \\
\text { efficient frontier. }\end{array}$ & $\begin{array}{l}\text { Allow (mainly SFA) sort out the efficiency } \\
\text { component from the error component. }\end{array}$ \\
Allow a dynamic analysis \\
\hline Drawbacks & $\begin{array}{l}\text { Cannot sort out the efficiency component from } \\
\text { the error component. } \\
\text { Cannot allow dynamic analysis. }\end{array}$ & $\begin{array}{l}\text { Require to know the cost or production } \\
\text { functional forms. }\end{array}$ \\
Need a large number of observations. \\
\hline
\end{tabular}

\section{Data and Model Specification}

\subsection{Choice of Variables}

The DEA approach is sensitive to the specification of both inputs and outputs and so variables' definition will influence the results. Inputs can be represented by physical or monetary measures. The former measure is mainly used in studies that focus on the technical efficiency of organizations (Carrington et al., 2002). In the present case, physical inputs respect to the labour force and the equipment set needed for the activity like connections to end-users, regulating stations, meters and satellite plants. Monetary measures may better reflect the capital used in the activity. Natural gas is a highly capital intensive activity where the CAPEX (investment costs) weight is superior to the OPEX (operating costs) weight. In the present case, this is not that straightforward since a few 
activities of the responsibility of the distributors are outsourced. When firms outsourced, they do not have to use their physical resources, being the costs registered on the External Supplies and Services accounting line. Thus in the present case, physical measures should not be used when evaluating potential efficiency gains. In order to account for this reality, the analysis will focus on accountability data where inputs will correspond to the operating costs net of investment costs (OPEX).

Natural gas distribution may be associated with three main outputs: number of customers, volume of gas distributed and network length. These outputs are also the main choice from other studies. Carrington et al. (2002) opted for the capacity to deliver gas (in Joules), residential customers and other customers whereas Zorić et al. (2009) chose as outputs the gas supplied (in $\mathrm{m}^{3}$ ), peak demand ( $\mathrm{m}^{3} /$ day), number of customers and network length (in km). Erbetta and Rappuoli (2008) study used distributed gas and number of customers as outputs.

However, each output influences differently costs dynamics where the outputs that mostly influence costs are often designated by cost driver.

In the present case, the number of customers and the volume of gas distributed may be considered as cost drivers. Following a study from Gordon et al. (2003, p. 479), "volumetric returns to scale exist such that as the diameter of the pipe doubles, its volume increases by a factor of 4 , while its surface area only increases by a factor of $2 "$. The volume of gas distributed is highly correlated with the investments costs in the distribution of gas but while output is proportional to volume, the cost is proportional to surface area. On the other hand, an increase on the number of customers leads to higher operating and maintenance costs. In the Portuguese case, distribution networks are different across companies. Network distribution of Lisboagás is relatively old which requires higher maintenance efforts.

Hence, the number of customers is an important cost driver. However, gas delivered and network length are also relevant cost drivers and thus the decision to include it as outputs as well. In fact, accepted revenue of gas distribution activity varies with gas delivered. If accepted revenues do not reflect evolution of quantities then the risk associated with fluctuating quantities is fully transmitted to consumers.

Exogenous factors can also influence the gas distribution activity like population density, climate, macroeconomic shocks and others. Once set the efficient attainable costs for a given level of outputs, it is crucial to verify if the distance from the frontier is exclusively due to the conduct firm or it may also be explained by other factors outside from the control of the firm. 
In order to better understand the several relationships between variables and consequently ensure that the cost driver's choice is the most accurate one, a dynamic analysis has been undertaken. The independent variables are represented by the total number of customers, gas delivered and network length. The dependent variable corresponds to the OPEX costs (at constant prices). The analysis includes six concession companies (Beiragás, Portgás, Tagusgás, Lusitaniagás, Lisboagás and Setgás) and four from the five licensed companies (Duriensegás, Sonorgás, Dianagás and Medigás) ${ }^{4}$. Table 3 provides a correlation analysis for the independent variables. Due to the highly correlation between those variables models, we discard models' results with more than $\mathbf{1}$ independent variable.

Table 3 - Correlation between independent variables

\begin{tabular}{|c|c|c|c|}
\hline & $\begin{array}{c}\text { Total } \\
\text { Customers }\end{array}$ & $\begin{array}{c}\text { Gas } \\
\text { delivered }\end{array}$ & $\begin{array}{c}\text { Network } \\
\text { length }\end{array}$ \\
\hline Total Customers & 1,00 & & \\
\hline Gas delivered & 0,99 & 1,00 & \\
\hline Network length & 1,00 & 0,99 & 1,00 \\
\hline
\end{tabular}

Table 4 reports the estimations results of three different panel data models: the first one with 10 companies (without Paxgás), the second includes the licensed companies data and the third regards only to the four biggest firms (Lisboagás, Lusitaniagás, Setgás and Portgás). In order to avoid multicollinearity, it was decided to consider only the number of customer as independent variable.

Overall, an increase in the number of customers' leads to an increase less than the proportional of the OPEX costs, which it might be translated into economies of scale. However, these results differ in the third model regarding the four biggest firms. In fact, an increase in the number of customers leads to an increase more than the proportional of the OPEX costs, which could be translated as diseconomies of scale.

This analysis ensures that the number of customers is a cost driver in the Portuguese natural gas distribution. Further analyses were made in order to investigate the gas delivered and network length as outputs. In fact, it was not conclusive that the number of customers is the only cost driver, not rejecting the hypothesis of natural gas quantities delivered and network length being also cost drivers.

Table 4 - Panel data results

\footnotetext{
4 The decision not to include Paxgás was mainly because it only presents operational activity since 2008.
} 


\begin{tabular}{|c|c|c|c|c|c|}
\hline Companies & Period & No. Obs & Effects & $\begin{array}{c}\text { Independent } \\
\text { Variable }\end{array}$ & $\begin{array}{l}\text { Coefficient } \\
\text { independent variable } \\
\text { (t-stat.) }\end{array}$ \\
\hline \multirow{2}{*}{ All } & $2005-2007$ & 30 & Fixed & $\begin{array}{l}\text { constant } \\
\text { Log customer }\end{array}$ & $\begin{array}{r}5,772 \\
(13,30) \\
0,869 \\
(20,93) \\
\end{array}$ \\
\hline & 2005-2007 & 30 & Random & $\begin{array}{l}\text { constant } \\
\text { Log customer }\end{array}$ & $\begin{array}{r}5,75 \\
(13,32) \\
0,810 \\
(21,1) \\
\end{array}$ \\
\hline \multirow{2}{*}{ Licensed } & $2005-2007$ & 12 & Fixed & $\begin{array}{l}\text { constant } \\
\text { Log customer }\end{array}$ & $\begin{array}{r}8,87 \\
(5,37) \\
0,50 \\
(2,62) \\
\end{array}$ \\
\hline & 2005-2007 & 12 & Random & $\begin{array}{l}\text { constant } \\
\text { Log customer }\end{array}$ & $\begin{array}{r}7,75 \\
(5,09) \\
0,63 \\
(3,60) \\
\end{array}$ \\
\hline \multirow{2}{*}{$\begin{array}{l}\text { Lisboagás, Portgás } \\
\text { Lusitaniagás, Setgás }\end{array}$} & 2003-2007 & 20 & Fixed & $\begin{array}{l}\text { constant } \\
\text { Log customer }\end{array}$ & $\begin{array}{r}1,89 \\
(2,38) \\
1,188 \\
(18,08) \\
\end{array}$ \\
\hline & 2003-2007 & 20 & Random & $\begin{array}{l}\text { constant } \\
\text { Log customer }\end{array}$ & $\begin{array}{r}1,99 \\
(2,69) \\
1,180 \\
(19,27)\end{array}$ \\
\hline
\end{tabular}




\subsection{Data}

This paper compares the performance of 11 gas distributors in Portugal for the year of 2008 as well as for the gas year 2008-20095.

Table 5 gives the summary statistics of the key variables used in the analysis. The input is the OPEX cost (at constant prices) whereas the number of customers, network length (in $\mathrm{km}$ ) and delivered gas (in $1000 \mathrm{~m}^{3}$ ) represent the outputs. There is a relatively high spread between the minimum and maximum values which reflects the differences in firm's size.

Table 5 - Summary of descriptive statistics, 2008

\begin{tabular}{lcccc} 
& $\begin{array}{c}\text { Operating Costs } \\
\text { (at constant prices) }\end{array}$ & $\begin{array}{c}\text { Number of } \\
\text { Customers }\end{array}$ & $\begin{array}{c}\text { Gas delivered } \\
\left(1000 \mathrm{~m}^{3}\right)\end{array}$ & $\begin{array}{c}\text { Network length } \\
(\mathrm{km})\end{array}$ \\
\hline No. observations & 11 & 11 & 11 & 11 \\
\hline Measure & $10^{3} \mathrm{EUR}$ & No. & $10^{3} \mathrm{~m}^{3} \mathrm{NG}$ eq. & $\mathrm{km}$ \\
\hline Minimum & 274 & 672 & 109 & 25 \\
\hline Maximum & 27545 & 475912 & 661305 & 3985 \\
\hline Average & 5614 & 96896 & 178738 & 1252 \\
\hline 95\% confidence interval & 5282 & 96823 & 168444 & 944 \\
\hline Median & 2866 & 21347 & 46667 & 640 \\
\hline Standard deviation & 7862 & 144122 & 250732 & 1406 \\
\hline \hline
\end{tabular}

Table 6 reports the descriptive statistics for the gas year between July, 1 of 2008 and June, 30 of 2009. For this dataset, it was not available enough information about the network length. Notice that, for the gas year 2008-2009, both the OPEX costs and the number of customers have higher maximums and averages than for the dataset of 2008.

Table 6 - Summary of descriptive statistics, 2008-2009 (gas year)

\begin{tabular}{lccc} 
& $\begin{array}{c}\text { Operating Costs } \\
\text { (at constant prices) }\end{array}$ & $\begin{array}{c}\text { Number of } \\
\text { Customers }\end{array}$ & $\begin{array}{c}\text { Gas delivered } \\
\left(1000 \mathrm{~m}^{3}\right)\end{array}$ \\
\hline No. observations & 11 & 11 & 11 \\
\hline Measure & $10^{3}$ EUR & No. & $10^{3} \mathrm{~m}^{3} \mathrm{NG}$ eq. \\
\hline Minimum & 220 & 1579 & 471 \\
\hline Maximum & 34965 & 480651 & 637549 \\
\hline Average & 6717 & 99899 & 176839 \\
\hline 95\% confidence interval & 2990 & 23125 & 47227 \\
\hline Median & 6829 & 98109 & 162685 \\
\hline Standard deviation & 10166 & 146036 & 242160 \\
\hline \hline
\end{tabular}

\footnotetext{
${ }^{5}$ In Portugal, the gas tariffs are set between July, 1 and June, 30 of the following year. This is designated as the gas year.
} 


\subsection{Estimation Results}

The DEA method is applied in order to determine the $X$-factors needed in the pricecap regulation. DEA models for each dataset were constructed, four for the year 2008 and three for the gas year 2008-2009. The models differ according to the outputs considered:

- Model 1: number of customers, delivered gas and network length

- Model 2: number of customers and delivered gas

- Model 3: number of customers

- Model 4: delivered gas

It was applied both a CRS-DEA model and a VRS-DEA model. However, in the case of natural gas distribution there are strong evidences of scale effects and thus it will only be provided the estimation results for the VRS-DEA models. In fact, the clearly sizeable differences among firms enhance the relevance of the VRS-DEA models against the CRSDEA. Table 7 reports the scale effects for each firm and for each model for 2008. The scale effects of each firm can be: (I) increasing returns to scale, arise when a firms is below the minimum efficient scale or the optimal point; (II) decreasing returns to scale, above the minimum efficient scale and (III) constant returns to scale, at the optimal point. Almost all firms are producing below their minimum efficient scale, except Portgás and Lisboagás (in the first three models) and Lusitaniagás, in the third model.

Table 7 - Scale effect analysis, 2008

$\begin{array}{lcccc} & \text { Model 1 } & \text { Model 2 } & \text { Model 3 } & \text { Model 4 } \\ \text { Beiragás } & \text { Increasing } & \text { Increasing } & \text { Increasing } & \text { Increasing } \\ \text { Dianagás } & \text { Increasing } & \text { Increasing } & \text { Increasing } & \text { Increasing } \\ \text { Duriensegás } & \text { Increasing } & \text { Increasing } & \text { Increasing } & \text { Increasing } \\ \text { Portgás } & \text { Decreasing } & \text { Decreasing } & \text { Decreasing } & \text { Increasing } \\ \text { Lisboagás } & \text { Decreasing } & \text { Decreasing } & \text { Decreasing } & \text { Increasing } \\ \text { Lusitaniagás } & \text { Constant } & \text { Constant } & \text { Decreasing } & \text { Constant } \\ \text { Medigás } & \text { Constant } & \text { Increasing } & \text { Increasing } & \text { Increasing } \\ \text { Paxgás } & \text { Increasing } & \text { Increasing } & \text { Increasing } & \text { Increasing } \\ \text { Setgás } & \text { Constant } & \text { Constant } & \text { Constant } & \text { Increasing } \\ \text { Sonorgás } & \text { Increasing } & \text { Increasing } & \text { Increasing } & \text { Increasing } \\ \text { Tagusgás } & \text { Increasing } & \text { Increasing } & \text { Increasing } & \text { Increasing }\end{array}$

Table 8 shows the efficiency scores for the Portuguese gas distributors, except for Paxgás, for the year 2008. Firms that present efficiency scores equal to 1, it means that it is on the efficient frontier or that it lays on the surface. Different distances from the frontier 
will be proportional according to the difference between the unit and the computed score by the DEA.

Firms could be separated by the following groups:

- Group 1: Portgás, Lusitaniagás and Medigás

- Group 2: Dianagás, Lisboagás and Setgás

- Group 3: Beiragás, Duriensegás and Tagusgás

- Group 4: Sonorgás

\begin{tabular}{lrrrr}
\multicolumn{5}{c}{ Table 8 - VRS-DEA, 2008 (without Paxgás) } \\
Beiragás & Model 1 & Model 2 & Model 3 & Model 4 \\
Dianagás & 0,64 & 0,55 & 0,54 & 0,34 \\
Duriensegás & 0,88 & 0,88 & 0,88 & 0,88 \\
Portgás & 0,57 & 0,40 & 0,40 & 0,29 \\
Lisboagás & 1,00 & 1,00 & 1,00 & 0,70 \\
Lusitaniagás & 1,00 & 1,00 & 1,00 & 0,23 \\
Medigás & 1,00 & 1,00 & 0,95 & 1,00 \\
Setgás & 1,00 & 1,00 & 1,00 & 1,00 \\
Sonorgás & 1,00 & 1,00 & 1,00 & 0,38 \\
Tagusgás & 0,32 & 0,29 & 0,29 & 0,29 \\
\hline & 0,58 & 0,35 & 0,28 & 0,35
\end{tabular}

The following analysis addresses the relationship between the efficiency scores obtained from the VRS-DEA and the exogenous variables. As has already been noted from the analysis made on Section 2.2, exogenous factors such as maturity and population density may have strong impacts on the performance of each gas distributor. Therefore, it is crucial to cross the scores obtained with the exogenous factors in order to investigate if the results have well been given by each firm or if they can be explained by other factors outside of the firms' control. From table 9, population density and maturity are related with three of the four estimated models at a $10 \%$ significance level.

Table 9 - Exogenous Factors vs. DEA results, 2008 (without Paxgás)

\begin{tabular}{|c|c|c|c|}
\hline & & Population Density & Maturity \\
\hline \multirow{3}{*}{ Model 1} & Number of customers & \multirow{3}{*}{2,26} & \multirow{3}{*}{3,36} \\
\hline & Network length & & \\
\hline & Delivered gas & & \\
\hline \multirow{2}{*}{ Model 2} & Number of customers & \multirow{2}{*}{2,30} & \multirow{2}{*}{2,69} \\
\hline & Delivered gas & & \\
\hline Model 3 & Number of customers & 2,37 & 2,53 \\
\hline Model 4 & Delivered gas & $-0,37$ & 0,28 \\
\hline
\end{tabular}


Notice that Portgás presents the highest population density, fact that might helps explaining the good performance given by the DEA scores. Therefore, it was decided to rectify the conclusions made before:

- Group 1: Lusitaniagás and Medigás

- Group 2: Dianagás, Lisboagás, Portgás and Setgás

- Group 3: Beiragás, Duriensegás and Tagusgás

- Group 4: Sonorgás

When considering the period 2008-2009 (gas year), the scale effects analysis has the follow results:

Table 11 - Scale effect analysis, 2008-2009

\begin{tabular}{lccc} 
& Model 2 & Model 3 & Model 4 \\
\hline Beiragás & Increasing & Increasing & Increasing \\
Dianagás & Increasing & Increasing & Increasing \\
Duriensegás & Increasing & Increasing & Increasing \\
Portgás & Decreasing & Decreasing & Increasing \\
Lisboagás & Decreasing & Decreasing & Increasing \\
Lusitaniagás & Constant & Decreasing & Constant \\
Medigás & Increasing & Increasing & Increasing \\
Setgás & Constant & Constant & Increasing \\
Sonorgás & Increasing & Increasing & Increasing \\
Tagusgás & Increasing & Increasing & Increasing
\end{tabular}

In this case, the first model was not able to be estimated due to missing data related to the network length. From the results above, firms are redistributed by the next order of efficiency:

- Group 1: Lusitaniagás, Medigás and Portgás

- Group 2: Dianagás, Lisboagás, and Setgás

- Group 3: Duriensegás, Sonorgás and Tagusgás

- Group 4: Beiragás

Table 12 - VRS-DEA, 2008-2009 (without Paxgás)

$\begin{array}{lrrr} & \text { Model 2 } & \text { Model 3 } & \text { Model 4 } \\ \text { Beiragás } & 0,60 & 0,57 & 0,46 \\ \text { Dianagás } & 0,88 & 0,88 & 0,88 \\ \text { Duriensegás } & 0,68 & 0,67 & 0,58 \\ \text { Portgás } & 1,00 & 0,95 & 0,74 \\ \text { Lisboagás } & 1,00 & 1,00 & 0,24 \\ \text { Lusitaniagás } & 1,00 & 0,83 & 1,00 \\ \text { Medigás } & 1,00 & 1,00 & 1,00 \\ \text { Setgás } & 1,00 & 1,00 & 0,51 \\ \text { Sonorgás } & 0,65 & 0,65 & 0,65 \\ \text { Tagusgás } & 0,75 & 0,40 & 0,75\end{array}$


VRS-DEA technical efficiency scores are regressed against population density and maturity to assess their impact on efficiency. The t-statistics (table 13) showed that population density is highly significance for model 2 and 3 (10\% significance level) whereas maturity variable is only $10 \%$ significance for the second model. Based on these results, the groups are once again redistributed, as follows:

- Group 1: Lusitaniagás, Medigás and Portgás

- Group 2: Dianagás, Lisboagás, and Setgás

- Group 3: Beiragás, Duriensegás, Sonorgás and Tagusgás

Table 13 - Exogenous Factors vs. DEA results, 2008-2009 (without Paxgás)

\begin{tabular}{|c|c|c|c|}
\hline & & Population Density & Maturity \\
\hline Model 2 & $\begin{array}{l}\text { Number of customers } \\
\text { Delivered gas }\end{array}$ & 2,52 & 2,47 \\
\hline Model 3 & Number of customers & 2,52 & 1,63 \\
\hline Model 4 & Delivered gas & $-1,48$ & $-0,63$ \\
\hline
\end{tabular}

\subsection{Implications on $X$-Factors}

Despite the high differences among the results of each dataset, results by group appear to be similar. The first group that defines the efficient frontier includes Medigás, Lusitaniagás and Portgás. The second group incorporates Dianagás, Lisboagás and Setgás. And the last group includes the remaining companies (Beiragás, Duriensegás, Sonorgás and Tagusgás). For any model, the third group presents average differential efficiency targets around 30\%, whereas the second group has an average differential efficiency roughly $15 \%$.

Table 14 - Annual $X$-Factors 


\begin{tabular}{lr} 
& $\begin{array}{c}\text { Efficiency } \\
\text { Factor } \\
\%\end{array}$ \\
\hline \hline Beiragás & 3,0 \\
\hline Dianagás & 0,5 \\
\hline Duriensegás & 1,5 \\
\hline Portgás & 1,5 \\
\hline Lisboagás & 3,0 \\
\hline Lusitaniagás & $\mathbf{0 , 5}$ \\
\hline Medigás & 1,5 \\
\hline Setgás & 0,5 \\
\hline Sonorgás & 3,0 \\
\hline Tagusgás & $\mathbf{3 , 0}$ \\
\hline \hline
\end{tabular}

Table 14 reports the annual $X$-factors decision where the minimum value, $0.5 \%$, represents potential efficiency improvements resulting from technological progress.

The decision to not include Paxgás was mainly due to its relatively low dimension and its low maturity.

\section{Regulatory implications}

In this paper, it was addressed a performance analysis of the Portuguese gas distributors in order to implement an incentive based regulation. Benchmarking allows determining the $X$-factors for each firm in order to improve efficiency. However, regulators or decision-making task does not end with $X$-factors estimation. There is also the necessity to determine the best attainable cost basis that the efficiency targets will be applied on. The next figure provides the different stages of an incentive regulation.

Figure 3 - Parameters to be determined under the price-cap regulation

\begin{tabular}{|l|l|}
\hline $\begin{array}{l}\text { - Efficiency targets by firm } \\
\text { - Weight of fixed and variable components of the OPEX }\end{array}$ \\
\hline
\end{tabular}


The share of costs into fixed and variable terms is not an easy assignment. This division depends on the horizon considered and also on the dynamics of each company. There are certain operating costs that change with the activity in the short- or mediumrun such as meter reading and customer support and assistance. However, it is hard to justify that the remaining costs may directly change with the activity in a 3-year horizon, the Portuguese energy regulatory period. The existing differences among firms regarding the maturity and the evolution of each firm may also lead to a further need of treating differently each distributor in terms of fixed costs.

From the empirical analysis made on Section 5.1, only the four biggest firms demonstrated to be on a stability phase whereas the remaining ones are on their introduction life cycle phase or in their growth phase. Moreover, Lisboagás, who inherited an aging network, witnessed a non-stationary trend of its costs over the period 20052007. Notice that Setgás has a lower dimension in comparison to Portgás and Lusitaniagás. The model presented on Section 5.1 was once more estimated but only considering Portgás and Lusitaniagás in order to compute the cost percentage for both firms that change directly with the activity. It was concluded that $40 \%$ and $60 \%$ of the operating costs, respectively for Lusitaniagás and Portgás, had positive and significant effects on the independent variable. Regarding the data available, it was decided to split the firms into just two groups, being $60 \%$ of the variable costs for the biggest firms and $80 \%$ for the remaining firms, as it can be observed in the next table.

Table 15 - Variable Costs Component (in \%)

\begin{tabular}{ll}
\hline Beiragás & $\mathbf{6 0 \%}$ \\
\hline Portgás & $\mathbf{6 0 \%}$ \\
\hline Setgás & $\mathbf{6 0 \%}$ \\
\hline Dianagás & $\mathbf{8 0 \%}$ \\
\hline Duriensegás & $\mathbf{8 0 \%}$ \\
\hline Lusitaniagás & $\mathbf{6 0 \%}$ \\
\hline Lisboagás & $\mathbf{6 0 \%}$ \\
\hline Medigás & $\mathbf{8 0 \%}$ \\
\hline Tagusgás & $\mathbf{6 0 \%}$ \\
\hline Sonorgás & $\mathbf{8 0 \%}$ \\
\hline
\end{tabular}

When setting $X$-factors in gas distribution, scale effects should be considered. The scale factor might not be under firms' control as exemplified by licensed or concession areas attributed to firms or by the maturity of each firm. Therefore, it was decided to apply a VRS-DEA model which beneficiated firms with smaller dimension. However, the smaller 
firms are also the most recent ones and apparently the most dynamics. These firms have a high growth rate and a possible diminishing of structure costs per unit of output in the following years. Thus it would be important to relate costs' evolution with the growth rate of each firm. Nevertheless, such implementation is very hard in regulatory terms.

In order to differentiate the firms capable of decreasing its unit costs due to their activity growth, it was decided to add a scale factor in the $X$-factors. Table 16 presents the scale factors. 
Table 16 - Scale factor (annual basis) \%

\begin{tabular}{ll}
\hline Beiragás & 0.5 \\
\hline Portgás & 0.0 \\
\hline Setgás & 0.0 \\
\hline Dianagás & 1.0 \\
\hline Duriensegás & 1.0 \\
\hline Lusitaniagás & 0.0 \\
\hline Lisboagás & 0.0 \\
\hline Medigás & 1.0 \\
\hline Tagusgás & 0.5 \\
\hline Sonorgás & 1.0 \\
\hline
\end{tabular}

Cost drivers choice is not completely neutral according to the risk share of the activity between firms and consumers. Regulated companies are usually compensated for their costs in particular the operating ones that change with delivered gas. If accepted revenues do not reflect evolution of quantities then the risk associated with fluctuating quantities is fully transmitted to consumers.

Moreover, the number of customers is not completely exogenous but rather is associated with the investment and management decisions of each firm. In Section 5.1 was referred that the number of customers is usually seen as a cost driver of the distribution of natural gas. This fact was pointed out by the panel data model. However, it was not conclusive that this variable is the only cost driver, not rejecting the hypothesis of natural gas quantities being also a cost driver.

The differences between $X$-factor applied into fixed and variable terms ${ }^{6}$ respect to the scale factors, as it can be observed on the consequent table. In global terms, it can be considered average $X$-factors weighted by the variable costs percentage provided in table 15.

Table 17 - $X$-factors (annual basis)

\footnotetext{
${ }^{6}$ For further developments see the Portuguese Natural Gas Tariff Regulation, specifically the $\mathrm{n}$ ㅇ 4 of the article $68 .^{\circ}$ present on the website www.erse.pt.
} 


\begin{tabular}{lccc} 
& X factor & X factor & X factor \\
& $\begin{array}{l}\text { Fixed term } \\
\%\end{array}$ & Variable term & Global weighted term \\
& $\%$ & $\%$ & 3.3 \\
\hline Beiragás & 3.0 & 3.5 & 0.5 \\
\hline Portgás & 0.5 & 0.5 & 1.5 \\
\hline Setgás & 1.5 & 1.5 & 2.3 \\
\hline Dianagás & 1.5 & 2.5 & 3.8 \\
\hline Duriensegás & 3.0 & 4.0 & 0.5 \\
\hline Lusitaniagás & 0.5 & 0.5 & 1.5 \\
\hline Lisboagás & 1.5 & 1.5 & 1.3 \\
\hline Medigás & 0.5 & 1.5 & 3.3 \\
\hline Tagusgás & 3.0 & 3.5 & 3.8 \\
\hline Sonorgás & 3.0 & 4.0 & \\
\hline
\end{tabular}

Table 18 provides the OPEX costs (fixed components) by firm that represents roundly $40 \%$ or $20 \%$ of the total costs for the first regulatory period. These values have by referee the net operating costs in 2008 (Portgás, Lisboagás, Lusitaniagás and Setgás) and in the gas year 2008-2009, for the remaining firms. The variable component is computed based on the physical values of 2008 and of the gas year. Furthermore, it is applied an inflation factor that takes care of the economy-wide price level.

Table 18 - Fixed and variable terms for the first regulatory period

\begin{tabular}{lrrr} 
& Fixed term & \multicolumn{2}{c}{ Variable term } \\
& $10^{3}$ Eur & $€ / \mathrm{m}^{3}$ & $\begin{array}{c}\text { no supply } \\
\text { points }\end{array}$ \\
\hline Beiragás & 1298 & 0.021 & 0.025 \\
\hline Portgás & 3665 & 0.005 & 0.014 \\
\hline Setgás & 2297 & 0.012 & 0.013 \\
\hline Dianagás & 183 & 0.077 & 0.089 \\
\hline Duriensegás & 327 & 0.045 & 0.033 \\
\hline Lusitaniagás & 3297 & 0.004 & 0.015 \\
\hline Lisboagás & 11353 & 0.170 & 0.018 \\
\hline Medigás & 154 & 0.053 & 0.025 \\
\hline Tagusgás & 1212 & 0.009 & 0.039 \\
\hline Sonorgás & 243 & 0.083 & 0.071 \\
\hline & & &
\end{tabular}

\section{Conclusion}


The Portuguese gas distribution has several specifications which did not allow the application of an incentive regulation in the first regulatory period. Efforts have been made in order to apply such regulation in the second regulatory period, 2010-2013, since the benefits appeared to be higher when compared to a rate-of-return regulation. Several issues related to data, such as small sample and missing data have been surpassed by applying the DEA. However, DEA is a partial and non-parametric approach which does not allow separating the effects of external factors of the effects of internal factors on the results.

Therefore, there are benchmark limitations. In that context, one couldn't directly apply the results obtained as efficiency targets. The main reasons are the uncertainty due to the data limitations, the regulatory framework and the weight of external factors. Besides the data limitation, this research suggests that the ability of Portuguese gas distributors to achieve efficiency differs strongly from firm to firm (as expected) mainly due to the referred external factors, than can be gathered.

Thus, Erse chose to not directly apply the results obtained as efficiency targets and on the other hand ERSE applied efficiency target by group of firms, with similar environmental characteristics, instead of by individual firms.

For further developments, it is necessary to continue analysing the performance of each firm in order to insure that efficiency is being attainable. Further efforts should be made in order to collect more and more reliable information about the Portuguese gas distributors. This improvement could actually influence results and strength the robustness of a future benchmarking analysis.

\section{References}

Averch, H. and Johnson, L., 1962, "Behaviour of the Firm Under Regulatory Constraint", American Economic Review, 52: 1053-1069.

Banker, R.D.; Charnes, R.F. and Cooper, W.W., 1984, "Some Models for Estimating Technical and Scale Inefficiencies in Data Envelopment Analysis". Management Science, 30:1078-1092.

Carrington, Roger; Coelli, Tim and Groom, Eric, 2002. "International Benchmarking for Monopoly Price Regulation: The Case of Australian Gas Distribution". Journal of Regulatory Economics, 21 (2): 191-216.

Charnes, A.; Cooper; W. W. and Rhodes, E., 1978. "Measuring the Efficiency of the Decision Making Units". European Journal of Operational Research, 2(4): 429 - 444.

Crew, Michael and Kleindorfer, Paul, 1996. "Incentive Regulation in the United Kingdom and the United States: Some Lessons”, Journal of Regulatory Economics, 9: 211-225. 
Erbetta, Fabrizio and Rappuoli, Luca, 2008. "Optimal scale in the Italian gas distribution industry using data envelopment analysis". Omega The International Journal of Management Science, 36(2): 325-336.

Farrell, M. J., 1957. "The Measurement of Productive Efficiency". Journal of the Royal Statistical Society, 120 (3): 253-290.

Farsi, Mehdi and Filippini, Massimo, 2004. "Regulation and Measuring Cost-Efficiency with Panel Data Models: Application to Electricity Distribution Utilities", Review of Industrial Organization, 25: 1-19.

Giannakis, Dimitrios; Jamasb, Tooraj and Pollitt, Michael, 2005. "Benchmarking and incentive regulation of quality of service: an application to the UK electricity distribution networks" Energy Policy, 33: 2256-2271.

Greene, William, 2008. "The Econometric Approach to Efficiency Analysis" Chapter 2 In The measurement of productive efficiency and productivity growth, Harold Fried, Knox Lovell, Shelton, Schmidt, (eds) Oxford: Oxford University Press.

Gordon, D.V; Gunsch, K. and Pawluk, C.V., 2003, "A natural monopoly in natural gas transmission", Energy Economics, 25: 473-485.

Haney, Aoife Brophy and Pollitt, Michael, 2009. "Efficiency Analysis of Energy Networks: an International Survey of Regulators", Energy Policy, 37(2): 5814-5830.

Hawdon, David, 2003. "Efficiency, performance and regulation of the international gas industry - a bootstrap DEA approach", Energy Policy, 31(11): 1167-1178.

Jamasb, T. and Pollitt, M., 2001. "Benchmarking and Regulation of Electricity Transmission and Distribution Utilities: Lessons from International Experience", Cambridge Working Papers in Economics 0101, Faculty of Economics, University of Cambridge.

Joskow, Paul L., 2005, "Incentive Regulation In Theory And Practice - Electricity Distribution And Transmission Networks," Working Papers 0514, Massachusetts Institute of Technology, Center for Energy and Environmental Policy Research

Koopmans, T. C., ed., 1951, Activity Analysis of Production and Allocation. New York: Wiley

Littlechild, Stephen C., 1983. "Regulation of British Telecommunications' Profitability". London: Department of Trade and Industry.

Lovell, Knox, 1992, "Production Frontiers and Productive Efficiency" Chapter 1 In The Measurement of Productive Efficiency: Techniques and Applications. H. Fried, K. Lovell and S. Schmidt (eds), Oxford: Oxford University Press.

Murillo-Zamorano, Luis R., 2004, "Economic Efficiency and Frontier Techniques". Journal of Economic Surveys, 18(1): 33-77.

Tirole, Jean, 1988. “The Theory of Industrial Organization”, Cambridge: MIT Press. 
Vogelsang, Imgo, 2002, "Incentive Regulation and Competition in Public Utility Markets: A 20-Year Perspective”, Journal of Regulatory Economics, 22(1): 5-27.

von Hirschhausen, Christian; Cullmann, Astrid and Kappeler, Andreas, 2006. "Efficiency analysis of German distribution utilities - non-parametric and parametric tests", Applied Economics, vol.38: 2553-2566.

Zorić, Jelena; Hrovatin, Neventa and Scarsi, Gian Carlo. 2009. "Gas Distribution Benchmarking of Utilities from Slovenia, the Netherlands and the UK: an Application of Data Envelopment Analysis", The South East European Journal of Economics and Business, 4(1): 113-124. 